\title{
INFORMATION POLICY IN THE ENVIRONMENTAL SPHERE IN THE CONTEXT OF SUSTAINABLE DEVELOPMENT OF UKRAINE AND THE EU
}

\begin{abstract}
Viktor LADYCHENKO, Department of International Law and Comparative Law, Law Faculty, National University of Life and Environmental Sciences of Ukraine, 15 Heroiv Oborony Str., Kyiv, Ukraine, ndi_land_law@ukr.net

The purpose of this research is to develop a legal mechanism for ensuring the right to access environmental information to ensure sustainable development of society. In the context of our study we developed an understanding of information human rights - the right to collect, disseminate, use and preserve environmental information is fundamental and natural.

We understand information human rights as a group of rights with a center around freedom of information, the right to environmental information, the right to communication in environmental sphere, the right to access to environmental information that is public or socially significant, the right to privacy, and the protection of personal data.

In the EU, access to environmental information is regulated by Directive 2003/4/EC (Aarhus Convention, 1998). Citizens of the EU have the right to receive this information within one month from the moment they ask and not to mention why they need it. In addition, public authorities are required to actively disseminate information on environmental information at their disposal.

In Ukraine defined system of a jurisdiction whose collection includes different types of environmental information and formation of information on environmental policy. But the issue of public administration in the field of environmental protection is currently split between different executive bodies; there is no united information policy and the body responsible for it. There is no obligation for the authorities to inform the population even in crisis situations.

This study will form the legal framework to ensure the right of access to environmental information in Ukraine by introducing the position of Information Commissioner - an official, the competence of which includes monitoring of compliance of information law with information policy in the environmental field.
\end{abstract}

Keywords: environmental information, information human rights, Information Commissioner, sustainable development.

\section{INTRODUCTION}

Legal regulation of information is a global problem. In the context of the formation of a global information society, a global issue of ensuring general access to environmental information is emerging. This corresponds to Ukraine's international commitments to ensure the ecological safety of mankind. Climate change and the fight against global warming are one of the global challenges that the global community faces today. Article 14 of the Paris Agreement provides for a so-called global summing up. The outcome of the global summing up should serve as an information basis for the Parties, with the strengthening of nationally determined contributions in accordance with the provisions of the Paris Agreement (UNFCCC, 2015).

At the same time, Swiss climatologist (Rogelj, Joeri et al, 2016, pp.187) scares the devastating weather anomalies in the coming years. Improving the legal regulation of information in the field of environmental protection will allow the development and implementation of new principles of information law in the field of the environment, which will solve the problems of preventing environmental threats and obligations assumed by Ukraine after the ratification of the Paris Agreement on Climate, 2015. However, from August 2015 to September 2017 Ukraine was disconnected from the Register by the International Journal of Transactions on anthropogenic emissions and removals of greenhouse gases (Ukrainian Register of Carbon Units, 2017).

\section{METHODOLOGY OF THE RESEARCH}

Scientific publications on information policy in environmental sphere were analyzed to compare legal regulation of access to environmental information in Ukraine and the EU. The methods of comparative, analytical, logical and statistical analysis were used.

Providing public access to environmental information is a relatively new approach to environmental management in Ukraine. In this paper, we review the current situation in information policy in environmental sphere in Ukraine, discuss 
the problems related to this situation, and present recommendations for improvement. Ways of improving the mechanism for organizing the activities of state authorities and bodies of local self-government in order to provide the population with environmental information were proposed.

As a result of the study amendments to Ukrainian legislation were developed. We offer an interdisciplinary approach: integration of information law, environmental law, international law, human rights and national security. This will allow us to form a conceptual understanding of the legal regulation of information on the environment as an object of realization of information human rights and a component of national security in the context of environmental threats.

\section{FOCUS OF RESEARCH}

The purpose of our research work is to improve the changes to the mechanism for access to information and the right to environmental awareness. They should be the basis of the environmental monitoring system and control over the unified state civil protection system, control over the activities of the entities related to the production and consumption waste, their recycling, processing and utilization, as well as provide access to information about their activities and impact on the state of the environment.

\section{RESULTS}

\section{Features of formation of information policy of Ukraine in the information sphere}

Article 50 of the Constitution of Ukraine guarantees the right of free access to information on the state of the environment, the quality of food products and household items, as well as the right to distribute it. This information may not be made secret (Constitution of Ukraine, 1996). Thereby (Kregul et al, 2012, pp.84), citizens of Ukraine have the right:

to receive information on emergencies related to environmental pollution, which have arisen or may arise, and about the necessary security measures;

for compensation of damage caused to their health and property as a result of emergency situations related to the pollution of the environment of man-made and natural nature.

The subject of public interest is information that indicates a threat to state sovereignty, territorial integrity of Ukraine; ensures the realization of constitutional rights, freedoms and responsibilities; indicates the possibility of violation of human rights, misleading the public, harmful ecological and other negative consequences of activity (inactivity) of individuals or legal entities, etc. (Article 29 of the Law of Ukraine "On Information") (Law of Ukraine "On information", 1992).

As can be seen from this norm, the law broadly defines areas of public interest. It also clearly calls environmental information as a matter of public interest. The main sources of such information are environmental monitoring data, cadastres of natural resources, registries, automated databases, archives, as well as certificates issued by authorized state bodies, bodies of local self-government, public organizations and individual officials.

Ecological information support is carried out by state authorities and bodies of local self-government within their powers via:
a) a) preparation for consideration by the Verkhovna Rada of Ukraine of annual National Report on the state of the environment in Ukraine, and after it - publication in a separate edition - posting on the Internet;
b) annually informing the relevant councils and population about the state of the environment of the respective territories;
c) systematically informing the population through the mass media about the state of the environment, the dynamics of its changes, the source of pollution, the placement of waste or other changes in the environment and the nature of the impact of environmental factors on people's health;
d) immediate notification of emergency ecological situations;
e) the transfer of information received as a result of environmental monitoring by channels of information communications to bodies authorized to make decisions on the information received;
f) ensuring free access to environmental information that is not a state secret and is contained in lists, registers, archives and other sources.

However, there is no procedural order for providing environmental information, leading to irresponsibility of state bodies. There is also lack of information exchange between the authorities. The Ministry of Ecology and Natural Resources of Ukraine does not have a "Regulation on the procedure for providing environmental information". These shortcomings, in our opinion, should be eliminated.

According to Convention on Access to Information, Public Participation in Decision-Making and Access to Justice in Environmental Matters of June 25,1998 (Aarhus Convention) environmental information means any information in writing, audiovisual, electronic or any other material form about:

a) the state of such components of the environment as water, its components, its compliance with existing sanitary and hygienic norms, including genetically modified organisms and the interaction between these elements;

b) factors such as substances, energy, radiation, as well as activities or measures, including administrative measures, drinking water supply agreements, policies, legislation, plans and programs that affect or may 
affect the component indicators, which include: cost-benefit analysis and other economic analysis and assumptions used in the decision-making process on matters relating to the environment;

c) the state of health and safety of people, impact on people's lives.

Legislation of Ukraine today operates with several identical terms - information on the state of the environment and environmental information. At the same time, the legislative definitions of these terms are somewhat different. So, in some cases, definitions do not cover certain types of environmental information, some definitions are more detailed than others.

In the context of the divergence of the definitions contained in laws and the Aarhus Convention, definition contained in the Convention should be applied, because provisions of international treaties ratified by Ukraine have a higher legal force than laws of Ukraine if there are disagreements between their norms.

To ensure sustainable development of Ukraine and the EU, we are developing an understanding of the information rights of people - it is the right to collect, disseminate, use and store information on the basis of which informational relations arise, are fundamental, natural in nature, necessary for formation and development of individual for the proper functioning of the state (Vitiv, 2015).

By ratifying the Aarhus Convention in 2005 the EU committed itself to guaranteeing access to environmental information, public participation in environmental decisionmaking, and broad access to justice in environmental matters both at the national and the EU level (Schoukens, 2015). At regional level European Union has taken important steps to align Community legislation with provisions of Aarhus Convention. Namely, Community environment policy is based on integration of environmental protection into other policies and aims to protect the environment for future generations (Luttenberger, 2004). Furthermore court decisions in the EU have emphasized the importance of public participation to environmental justice and democracy (Bonorris, 2010).

Directive 2003/4/EC of the European Parliament and of the Council of 28 January 2003 on public access to environmental information and repealing Council Directive 90/313/EEC provides citizens with the right to environmental information stored or produced by public authorities, including information on the state of the environment, as well as on policy or activities, or how this can affect the health and safety of people. Applicants are entitled to receive this information within one month from the time they ask for and not saying why they need it. In addition, there are public authorities which have to actively disseminate information on environmental information in their possession (Aarhus directive, 2003).

The European Commission monitors the implementation of EU legislation in EU member states to ensure that the laws are implemented in accordance with their intended objectives and that all EU countries comply with the agreed rules through reporting and monitoring using Shared Environmental Information System (SEIS). The European Environment Agency of course plays a crucial role in collecting and providing environmental information, with the help of its European environment information and observation network (EIONET). EIONET is a network of some 900 experts from over 300 national environment agencies and other bodies dealing with environmental information in 37 European countries, as well as five European Topic Centres (ETCs) working on specific environmental themes (European Environment Information..., 2017).

Society is informed about: the state of the environment (e.g., air limits, water conditions, etc.), emissions (for example, in the European Pollutant Release and Transfer Register), pressure (for example, according to the Marine Strategy Framework Directive), individual activities (e.g., in accordance with the Nitrate Directive), plans and programs (e.g. air quality management plans, river basin management plans, etc.), market surveillance (e.g. according to REACH), costs and benefits of actions (Ladychenko, V. et al, 2017).

Another positive EU experience which should be implemented in Ukraine derives from the EU Directive on Environmental Liability, which allows the public and nongovernmental environmental organizations to request competent authorities to intervene in cases of environmental damage or imminent threat (Dellinger, 2012). Public participation can help by adding another expert voice to the democratic discourse as well as to lawmaking and law enforcement processes (Toth, 2010). When discussions and negotiations on the protection of the environment, on the balancing of ecological with other interests take place in the remoteness of administrative offices or behind closed windows, the environment almost always is the loser; only when the discussions are transparent and public, is there a chance that the considerations of the protection of the environment prevail over vested interests. This aspect links the citizen's right of access to information which is directed against public administration, to the specific concern for the environment (Krämer, 2013).

The right to access to environmental legislation is enshrined in Ukrainian legislation, but the right to effective and accessible procedures to enable individuals to seek all relevant and appropriate environmental information, and to participate in environmental decision making, when their right to life, or/and their right to respect for private and family life, are threatened is not legally regulated. That is why it is necessary to use EU experience in this sphere. Procedural environmental rights provide several benefits to the public. They serve to: raise awareness of the state of the environment and possibly motivate behavioural change; facilitate gathering of information for sounder environmental decisionmaking, which in turn likely increases legitimacy of, and buy-in into, resulting decisions; facilitate accountability of government and others (including private entities, to some extent) as regards environmental protection throughout the policy process, with increased scrutiny likely to lead decision makers to give greater weight to environmental considerations and adhere more closely to environmental policy and law); and enable improved implementation and enforcement of environmental law (in a climate of limited state resources and given the widespread nature of environmental harm), by empowering the public to control public authorities' environmental decisions and protect their rights dependent on a healthy environment which may be/have been affected by the proposed decision (Kimber, 1998). 
But at the same time public participation requires that people and population groups need to understand the policies in order to choose the ones that match their needs (Vanheusden, 2016).

In Ukraine, environmental information can be presented on the example of information on the status of water resources. In Ukraine water supply systems are mostly morally and physically obsolete. Ukrainians drink mainly water from rivers - it is $80 \%$ of water, the remaining $20 \%$ is taken from underground fresh water. Problems with the quality of drinking water are complex: worn out water and pump stations, treatment plants, outdated technological processes and negligent attitude to water purification after use from the side of local government and enterprises of different levels is the reason of poor quality of drinking water in our country. In addition, during transportation almost $25 \%$ of water is lost.

The central water supply is used by more than $70 \%$ of the population of Ukraine. These are all major cities, almost $90 \%$ of urban settlements and $23 \%$ of villages. According to Ukrstat (data without taking into account the occupied territories), in 2015 9,7 millions cubic kilometers of water were taken from natural sources. The capacity of treatment facilities is 5,8 millions cubic kilometers of water, that is, they cleared slightly more than half of the collected water, and the rest was not cleaned or was cleaned insufficiently qualitatively.

Water quality control is provided by the State Service of Ukraine for Food Safety and Consumer Protection. About 19,000 centralized drinking water supply systems are controlled by sanitary and epidemiological stations. But the number of pipelines that do not meet the standards is constantly increasing. During 9 months in 2015, 198 water facilities (from 11774 sources of centralized water supply) fell under control, of which at least $42(21 \%)$ did not meet the standards. In 127398 studies of drinking water for bacteriological indicators deviation was set in $6.4 \%$ of studies. In 151432 sanitary and chemical studies deviations were in $9.3 \%$. In the water of decentralized water supply, these figures turned out to be 2-3 times larger. Almost every forth sample had an increased content of nitrates, and these elements contribute to the formation of malignant tumors (Ladychenko, 2016, pp. 41).

Although the water utilities claim that after the treatment Ukrainian water meets EU standards, but still the liquid flows from the valves, which sometimes has a strange color and/or even a taste. The reason is usually found in the terrible condition of pipelines and water systems, which are often more than fifty years old, or even more. Their reconstruction needs huge amount of money, therefore, solving of this problem is postponed every time, and the problem remains chronically unresolved.

In accordance with the quality of water entering the house, residents of this house pay a reasonable price (worse quality - a lower price). That is why it is advisable:

- to improve the mechanism of access to information and implementation of the right to environmental awareness and put it at the core of the system of monitoring, control over the unified state system of civil protection and control over the activities of the entities related to production and consumption waste, their reuse, recycling and utilization (can be provided only if there is access to information about their activities and impact on the state of the environment).

- to analyze the changes in the organizational and legal mechanisms for ensuring the right to access environmental information in accordance with administrative and legal support of public authorities, bodies of local self-government, business entities in accordance with the Law of Ukraine "On Access to Public Information", the new edition of the Law of Ukraine "On information", the Law of Ukraine "On Environmental Protection" and other normative acts of information and environmental legislation.

Now the environmental management system is formed around its separate branches (air protection, waste management, protection and rational use of water resources, subsoil, etc.), at the same time there is no proper systematic exchange of information in electronic form. The issue of public administration in the field of environmental protection, which is currently divided between various executive authorities is the main difficulty.

In particular:

- the permitting system mainly concerns the competence of regional state administrations;

- the licensing system and individual permissions are within the competence of the Ministry of Environmental Protection;

- statistical authorities, the State Water Agency regarding the use of water resources, the State Service of Geology and Mineral Resources, etc. are responsible for the reporting;

- control over compliance with environmental legislation belongs to the State Environmental Inspectorate;

- taxes for the use of natural resources and pollution of the environment are collected by the State Fiscal Service.

This situation leads to the impossibility of providing the public and other interested parties with qualitative and complete information about the state of the environment. It also creates an additional permissive and controlling burden on business entities.

Integration of public administration in the field of environmental protection should be carried out in a comprehensive manner, both by industry (protection of atmospheric air, waste management, protection and rational use of water resources, mineral resources, etc.), and in functional areas (licensing system, monitoring system, etc.).

The current legal framework is formed on the basis of normative legal acts of 1990-1999, namely: Law of Ukraine "On Environmental Protection" of June 25, 1991. Analysis of the content of Art. 10 of the Law of Ukraine "On Environmental Protection" makes it possible to identify a number of information rights of citizens, which are implemented through the introduction of a mechanism for ensuring the implementation of state and public control over compliance with legislation on environmental protection, participation of public organizations and citizens in environmental protection, by creation and functioning of the network of the national ecological automated information-analytical system providing access to environmental information. By the resolution of the Cabinet of Ministers of Ukraine of March 30, 
1998, № 391 "On Approval of the Regulation on the State Environment Monitoring System" the regulation defines the system of bodies which competence includes collection of various types of information.

Disadvantages: The specifics of the envisaged exchange of information provides only collection and accumulation of information by the executive authorities. The Regulation does not reflect the information obligations of these bodies before the population.

\section{CONCLUSIONS AND DISCUSSION}

From the analysis we conducted, we should note the following ways to improve the mechanism for organizing the activities of state authorities and bodies of local self-government in order to provide the population with environmental information:

- It is necessary to include in the current legislation provisions that improve the mechanisms for ensuring information rights in the field of environmental protection.

These rights include freedom of information, the right to information, the right to access to information, the right to access to socially important information, the right to legal information, the freedom of thought, the belief, the right to protection of personal data (genetic information) and any information relating to private life, the right to destruction of personal data in automated systems.

- It is advisable to consolidate the right to environmental awareness, as an independent information law in the field of environmental protection which guarantees the right to live in a safe environment.

In order to ensure proper protection of the violated right to environmental awareness from untimely, incomplete or unreliable publication of data, we propose the introduction of changes to the current normative legal acts. In particular, the right to timely receive socially significant information about the state of drinking water from any information manager, which should bring it to the attention of the population, should be added in art. 9 of the Law of Ukraine "On Drinking Water and Drinking Water Supply".

Separately, it is necessary to supplement the mechanism for bringing to administrative, criminal, disciplinary responsibility for the failure of information managers to perform their duties.

It is necessary to create a single environmental control body and transfer all control functions to it, to take into account in its competence the requirements of the Directive 2010/75/EC on industrial emissions (integrated pollution prevention and control);

Improve informational and legal component of legislation by adopting the Regulation on the activities of territorial subdivisions of the State Security on the principle of ecological resources and ecologically-technogenic districts, local communities during the performance of the functions of environmental control (landslide, control of objects of the Natural Reserve Fund of local significance, hunting, poaching, waste management);

Implementation of regulatory requirements for automated systems in accordance with the recommendations of the UNECE Commission on the establishment of a European Observing Network and information on the state of the environment and experience of EUROWATERNET, EUROSOMNET, ICPFORESTS networks.

The introduction of an integrated electronic environmental management system, taking into account European approaches to the management of environmental information, will eliminate the "dispersion" of environmental information between various executive authorities, ensuring the availability of information not only about emissions to the environment, but also about permits, limits, decisions on impact assessments on the environment, etc. in a single database.

The system of e-government will also optimize and improve the efficiency of public administration in the field of environmental protection, reduce the reporting, permissive burden on business entities.

Environmental governance envisages the introduction of common state classifications in the field of environmental protection taking into account EU classifiers, development and implementation of the unified national identification system for objects that affect or can affect the environment, development and implementation of integrated electronic services for obtaining permits and submission of reports by environmental users.

It should be noted that the introduction of e-governance is in line with Ukraine's international commitments, in particular, is set out in the Association Agreement with the EU.

We consider it necessary to develop the concept of legal support for information and environmental security in accordance with the standards of international information and international environmental law.

\section{REFERENCES}

1. Bonorris, S., Targ, N. Environmental Justice in the Laboratories of Democracy, 25. Available at: https://gov.uchastings.edu/publiclaw/docs/NRE_FA10_bonorris_targ.pdf (Accessed on 26/01/2018)

2. Convention on Access to Information, Public Participation in Decision-Making and Access to Justice in Environmental Matters. 1998. Available at http://www.unece.org/fileadmin/DAM/env/pp/documents/cep43e.pdf (Accessed on 14/11/2017)

3. Dellinger, M.F. 2011. Ten Years of the Aarhus Convention: How Procedural Democracy Is Paving the Way for Substantive Change in National and International Environmental Law. https://doi.org/10.2139/ssrn.2004513

4. Directive 2003/4/EC of the European Parliament and of the Council of 28 January 2003 on public access to environmental information and repealing Council Directive 90/313/EEC. 2003. Available at http://eur-lex.europa.eu/legalcontent/EN/TXT/?uri=CELEX:32003L0004 (Aaccessed on 14/11/2017) 
5. European Environment Information and Observation network. 2017. Available at https://www.eionet.europa.eu/ (Accessed on 14/11/2017)

6. Kregul, Y., Ladychenko, V. Constitutional Law of Ukraine. 2012. p. 86-88.

7. Ladychenko, V. 2016. State policy on human rights for drinking water. Scientific notes of the Institute of Legislation of the Verkhovna Rada of Ukraine 3, pp. 39-43.

8. Ladychenko, V., Golovko, L. 2017. Implementation of European Environmental Policy in Ukraine: Problems and Prospects European. Journal of Sustainable Development, Vol. 6, No. 3, pp. 333-339

9. Law of Ukraine "On information”. 1992. Available at http://zakon0.rada.gov.ua/laws/show/2657-12 (Accessed on 14/11/2017)

10. Law of Ukraine "On the protection of the environment". 1991. Available at http://zakon2.rada.gov.ua/laws/show/1264-12 (Accessed on 14/11/2017)

11. Luttenberger, A., Rukavina, B. 2004. The right to access to information on environmental matters. Energy and the Environment, pp. 257-263.

12. Kimber, C. 1998. Understanding Access to Environmental Information: The European Experience. Law in Environmental Decision-Making: National, European and International Perspectives, Vol. 139, pp. 142-143.

13. Krämer, L. 2013. The EU, access to environmental information and the open society. Environmental Law Network International, pp. 38-43

14. Resolution of the Cabinet of Ministers of Ukraine "On Approval of the Regulation on the State System for Environmental Monitoring”. 1998. http://zakon0.rada.gov.ua/laws/show/391-98-\%D0\%BF (Accessed on 14/11/2017)

15. Rogelj, J., Knutti, R. 2016. Geosciences after Paris. Nature Geoscience, Vol. 9(3), pp. 187. https://doi.org/10.1038/ngeo2668

16. Schoukens, H. 2015. Access to Justice in Environmental Cases after the Rulings of the Court of Justice of 13 January 2015: Kafka Revisited? Utrecht Journal of International and European Law, Vol. 31(81). https://doi.org/10.5334/ujiel.di

17. The Constitution of Ukraine. 1996. Available at http://zakon3.rada.gov.ua/laws/show/254\%D0\%BA/96-\%D0\%B2\%D1\%80 (Accessed on 14/11/2017)

18. Toth, B. 2010. Public Participation and Democracy in Practice-Aarhus Convention Principles as Democratic Institution Building in the Developing World. Journal of Land Resources \& Environmental Law, Vol. 30, pp. 295-330.

19. Ukrainian Register of Carbon Units. 2017. Available at http://www.carbonunitsregistry.gov.ua/ (Accessed on 14/11/2017)

20. Squintani, L, Vanheusden, B, 2016. EU Environmental and Planning Law Aspects of Large-Scale Projects, $1^{\text {st }}$ ed., Intersentia Cambridge, Cambridge.

21. Vitiv V. 2015. The state policy in the field of drinking water and water supply in the light of the new doctrine of administrative law. Proceedings of the International Scientific Conference Legal Science: Challenges and the Present, pp. 69-73, Black Sea Foundation of Law. 